\title{
Developing a Social Network as a Means of Obtaining Entrepreneurial Knowledge Needed for Internationalization
}

\author{
Chen Han and Adeleye Afolabi
}

\author{
" (he hunger and thirst for knowledge, the keen delight in the") \\ chase, the good humored willingness to admit that the scent \\ was false, the eager desire to get on with the work, the cheerful \\ resolution to go back and begin again, the broad good sense, the \\ unaffected modesty, the imperturbable temper, the gratitude \\ for any little help that was given - all these will remain in my \\ memory though I cannot paint them for others.
}

Frederic William Maitland (1850-1906)

Jurist and historian

\begin{abstract}
An internationalization process for startups is based on the exchange of knowledge and other resources required for early internationalization and fast growth, and it requires ventures to identify opportunities, conduct business, and gain a competitive advantage in a foreign market. But, how do entrepreneurs obtain the knowledge required for internationalization? Previous research suggests a role for the utilization of social networks, leading managers to ask three basic questions: i) what kinds of knowledge-based resources are urgently needed by international new ventures?, ii) how do needs for knowledge change according to different stages in the internationalization process?, and iii) how can changing needs for knowledge be met by developing and leveraging a social network? In this article, we review the related literature, discuss potential answers to these basic questions, and we suggest how a dynamic process can guide new ventures to acquire knowledge for developing resources and conducting business toward internationalization.
\end{abstract}

\section{Introduction}

Internationalization is a challenging process, especially during the early stages of a firm. New ventures that wish to expand their business in new foreign markets have to overcome a lack of legitimacy and their liability of newness, smallness, and foreignness (Englis et al., 2007; Sepulveda \& Gabrielsson, 2013). Entrepreneurs have to rely on their networks to overcome their shortcomings.

Internationalization involves and requires the exchange of knowledge-based resources needed, directed towards recognizing opportunities to guide a business and also gain competitive advantages in the global market. Promoting the required processes leads to three basic questions asked by entrepreneurs and managers with the goal of expanding their business in new foreign markets:

1. What kinds of knowledge-based resources are urgently needed by international new ventures?

2. How do needs for knowledge change according to different stages in the internationalization process?

3. How can changing needs for knowledge be met by developing and leveraging a social network? 


\section{Obtaining Entrepreneurial Knowledge Needed for Internationalization}

Chen Han and Adeleye Afolabi

According to Sepulveda and Gabrielsson (2013), entrepreneurship research has a rich history of network studies, and many of them discuss how networks evolve through a domestic venture-creation process. Several studies have also demonstrated how social networks play an essential role in internationalization and resource acquisition. For example, global startups rely on networks to increase intangible content, including commercial knowledge, strategic information, and other valuable resources (Sepulveda \& Gabrielsson, 2013). Those firms placed centrally in a network could acquire more, better, and earlier knowledge and unexpected information compared to their competitors, which may influence their internationalization (Sharma \& Blomstermo 2003). However, previous research has rarely focused on the knowledge-based resources that are essential in the early stage of internationalization or how they are obtained. Previous researchers have generally overlooked changes in needs for knowledge during the dynamic venture process and how entrepreneurial networks develop to accommodate these different needs when entering a new foreign market (Slotte-Kock \& Coviello, 2010).

This lack of research on the dynamic process and pragmatic strategies for business relationship development motivated our study. In this article, we first categorize knowledge required for internationalization by new ventures (i.e., technological knowledge, experiential knowledge, foreign institutional knowledge, and business knowledge), and identify the most likely means of acquiring each type of knowledge. Second, we identify three stages of growth (i.e., foreign market intention, active involvement, and committed involvement) and how needs for knowledge change according to these stages. Third, we emphasize a pattern of leveraging initial networks in domestic markets to develop new business relationship in foreign markets, as well as strategies integrated with tie-strength theory for acquiring knowledge associated with different stages and requirements.

Owing to an extensive discussion of the solution in a dynamic process, this article could serve as a guide for new ventures in developing their ability to identify opportunities, acquire knowledge, and gain competitive advantage by facilitating and networking a collective set of relationships required for internationalization.

\section{Literature Review}

Previous research suggests a role for the utilization of social networks in acquiring knowledge for developing resources and conducting business toward internationalization. In this article, we review the related literature, discuss potential answers to the three basic questions described earlier: i) what kinds of knowledge-based resources are urgently needed by a international new ventures?, ii) how do needs for knowledge change according to different stages in the internationalization process?, and iii) how can changing needs for knowledge be met by developing and leveraging a social network?

Englis and colleagues (2007) see a global startup process as "a process of organisational emergence" where ventures are involved in the exchange of knowledge, information, and other valuable resources with international contacts to recognize and explore business opportunities in the global market. Internationalization depends on gaining competitive advantage from "the use of resources and the sale of outputs in various countries" (Oviatt \& McDougall, 1994). However, according to Sepulveda and Gabrielsson (2013), new international firms usually have to overcome a liability of newness (e.g., inadequate financing, knowledge, and experience), smallness (e.g., a lack of reputation and legitimacy), and foreignness (e.g., a lack of familiarity with varied international business environments) in their early stages. To overcome these shortcomings, global startups have to obtain critical resources required for their early internationalization and sustainable growth, not only internally but also beyond the boundaries of the organization, within their networks.

Knowledge is a key resource that plays an essential role in the development of global startups (Sepulveda \& Gabrielsson, 2013). Sharma and Blomstermo (2003) state that a firms' internalization process is "driven by their knowledge base". The firms' knowledge base encompasses a well-organized management of knowledge flows across its domestic borders, which is important for a firm success, especially in new growing firms that function under certain resource limitations (De Clercq \& Arenius, 2006). Seeking opportunities with little control over the required resources is a difficult task. Specific knowledge and information needed to "get things done quickly" has proven to play a key role in the success of most ventures, which shows its importance relative to access to capital resources (Kuemmerle, 2002). Furthermore, knowledge has direct impacts on the control and guidance of the venturing opportunity. The opportunities required by global startups are knowledge-intensive, as knowledge is the most important factor in their offering or a prerequisite in the development of their offering. Penrose (1959) articulated 


\section{Obtaining Entrepreneurial Knowledge Needed for Internationalization}

\section{Chen Han and Adeleye Afolabi}

that knowledge provides the best possible ways of understanding how initial ideas could be transformed into market offerings and also how entrepreneurs or firms can utilize such offerings. For example, technological knowledge and business knowledge could be used in assessing the feasibility and desirability of an offering, while knowing the clients' readiness and their decisionmaking process can lead to future business (Englis et al., 2007). Lastly, the ability to accumulate, manage, and mobilize knowledge to achieve specified business goals for growth are antecedents to successful entrepreneurship (Kuemmerle, 2002). For instance, knowledge shapes the "absorption capability" of the internationalizing firm, thereby forming a basis of the knowledge that the firm will be able to absorb in the future (Cohen \& Levinthal, 1990).

\section{What kinds of knowledge-based resources are urgently} needed by a global startup?

By synthesizing the related literature, we found that four types of knowledge are required by international new ventures, as described below and illustrated in (Figure 1).
First of all, technological knowledge is organized tacit knowledge that is associated with the firm's functionality and application offerings (Englis et al., 2007). The most resourceful way of extracting this kind of knowledge is through the combination of an international and domestic network because knowledge in relation to human resources can best be obtained internationally through sharing information with other business people, whereas that which is developed in R\&D facilities is much easier to obtain locally.

Second, experiential knowledge consists of knowledge about venturing, network experience, and internationalization, which is essential because firms tend to trust past knowledge accumulated from experience more than new information during an expansion process (Englis et al., 2007). Specifically, venturing knowledge is needed by firms to ensure sustainable creation of value through the exploitation of the venture opportunity (Van der Veen \& Wakkee, 2004). Network experiential knowledge could enhance the firms' capacity to identify and develop business relationships and conduct business in a network. Internationalization experiential

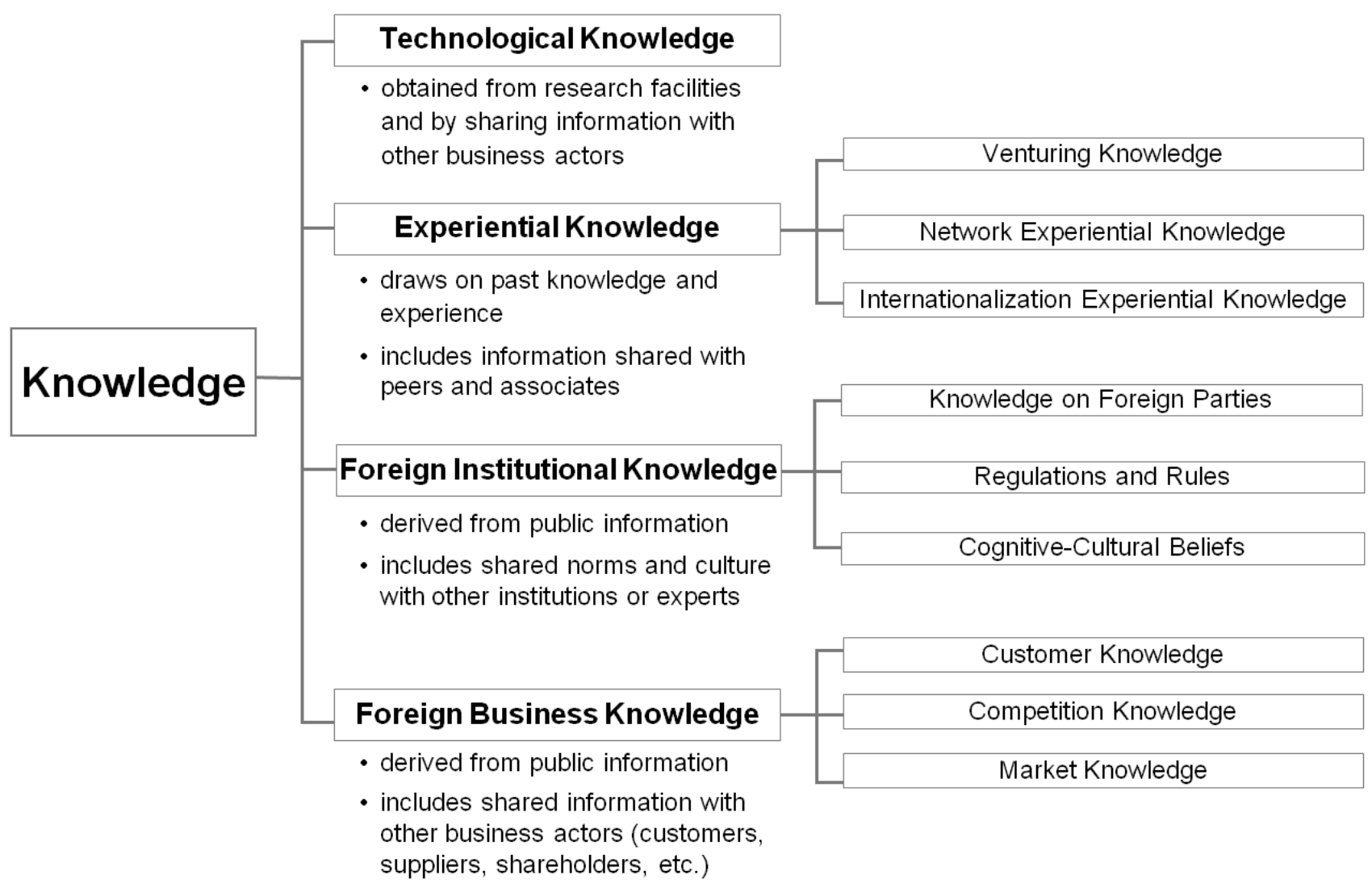

Figure 1. Types of knowledge required by international new ventures 


\section{Obtaining Entrepreneurial Knowledge Needed for Internationalization}

Chen Han and Adeleye Afolabi

knowledge is believed to help management teams possess and make use of more foreign strategic partners to grow faster than firms with less experiential knowledge. Generally, these three kinds of experiential knowledge could be gained from past experience, training, consultation, and "business operations in relation to other actors in networks" (Englis et al,. 2007).

Third, foreign institutional knowledge focuses on the knowledge about government, institutional frameworks, rules, norms, and cognitive-cultural beliefs (Eriksson et al., 1997). Javernick and Levitt (2009) suggest that international projects require managers to work with diverse participants in various countries, and are thereby faced with many challenges that arise from cross-national differences. Therefore, knowledge of these institutional elements is essential for sustainability and profitability for the firm, as well as being beneficial in reducing the risks of misunderstanding, delay, and cost in the global market. Also, explicit institutional knowledge is usually embedded in public information, such as local laws or research results, whereas tacit knowledge could be acquired through social processes, seeking information from experts in corresponding fields, and exchanging connections with other business people with related experience.

Fourth, foreign business knowledge includes knowledge on customers, suppliers, and competitors, which gives startups an advantage. This advantage comes about because business knowledge remain conducive to helping firms promote customers relationship, predict competitor behaviour, and react to market demands. Having knowledge about customers' willingness and ability to cooperate appears to be a foundation upon which a small or medium-sized business can expect its future business to develop. Also, knowledge associated with product offerings and the weaknesses and strengths of rivals and competitors, provides global startups with an improved offensive and defensive strategy with respect to identifying opportunities and threats (Fleisher \& Bensoussan, 2007), as well as developing competitive strategies to differentiate it from its competitors (Englis et al,. 2007). Market knowledge relates to "the desirability of the offering" (Van der Veen \& Wakkee, 2004) and concerns both "legislative and cultural issues, and also the socio-economic and technological landscape of the market" (Englis et al., 2007). In addition to acquiring this type of knowledge through public databases and research institutions, another effective means of acquiring less codified know- ledge or knowledge related to specific situations is through the exchange of information with other entrepreneurs, customers, suppliers, and other actors (Javernick et al., 2009).

\section{How do needs for knowledge change according to dif- ferent stages in the internationalization process?}

As discussed earlier, internationalization is the process of exchanging knowledge and other resources required by early internationalization and fast growth, to recognize opportunities, conduct business, and gain a competitive advantage in the foreign market. Internationalization has three stages, as identified by Coviello and Munro (1997):

1. Foreign market intention: In this stage, global startups have an intention to enter a foreign market. They discover profitable opportunities and prepare for the exploitation of these activities. During this stage, the process of opportunities discovery and preparation is affected by prior experiential and technological knowledge (Shane, 2000), as well as information regarding the business actors and demands in the target market. According to Englis, Wakkee, and van der Sijde (2007), the entrepreneurs "discuss their ideas and opportunities-in-progress with potential resource providers and prospective customers to develop an initial idea into a viable business opportunity by matching (future) attainable resources and perceived market needs". These authors also point out that initial ideas may be discovered in the domestic context, when startups are typically engaged in information exchanges with individuals and institutions located internationally.

2. Active involvement: In the second stage, entrepreneurs of global startups involve themselves in activities of "exploring the feasibility to create the business elements, mobilization of relevant suppliers, customers and partners, location of relevant resources and using the network to explore the novelty creation" (Englis et al., 2007). In this stage, experiential knowledge in venturing, networking, and internationalization, as well as foreign institutional knowledge, would significantly affect the activities in relation to exploring new markets and meeting resource needs required to act on opportunities. The types of knowledge required for this active involvement stage are often diverse or scattered around the world. So, the entrepreneur should be able to learn and internalize knowledge by interacting with diverse network ties and bridging previously unconnected parties (Sepulveda \& Gabrielsson, 2013). 


\section{Obtaining Entrepreneurial Knowledge Needed for Internationalization}

Chen Han and Adeleye Afolabi

3. Committed involvement: In the third stage, the entrepreneur focuses on creating desirable offerings and gaining competitive advantage. Firms require highly privileged information for "rare, non-imitable benefits" (Sepulveda \& Gabrielsson, 2013) as well as specialized knowledge in venturing and global business for "generating its own working capital" (Dyer, 1996) and strengthening market position. So, entrepreneurs must to seek and obtain such information and knowledge by building up a strong link with key stakeholders (Gabrielsson et al., 2008) and constantly expanding their social network to enhance their visibility and lower risks and uncertainty in new markets.

Table 1 summarizes the types of knowledge required by the entrepreneur through these three stages. At each stage, the needs for knowledge may be different, different means of obtaining this knowledge may be required, and there may be different ways that the knowledge can be "transformed, combined, or lead to a unique advantage" (Brush et al., 2001).

\section{How can changing needs for knowledge be met by de-} veloping and leveraging a social network?

International new ventures, with limited time and resources in their early stages, need to develop strategies that enable them to "create, obtain and control knowledge efficiently and effectively". With structures of relative stability and predictability, which reduce perceived uncertainty (Hakansson \& Snehota, 1995), and with systems of joint learning and distribution of information between the firms (Schumpeter, 1934), the use of networks is critical at this period. Founders rely on their networks to support their future establishment (Greve \& Salaff, 2003) and overcome their liabilities.

Also, most of the knowledge required for internationalization is experience-based or located internationally, meaning it is hard to acquire from traditional approaches. Although a social network is usually helpful for intangible resource exchange or overcoming geographical barriers. Hence, firms must gain knowledge through deliberate networking in both their domestic and foreign markets to meet knowledge needs.

Internationalization for entrepreneurs is usually opportunity driven and often depends on existing network relationships, such as for exchanging required knowledge from existing sources. Entrepreneurs also tends to gain legitimacy and increase the chances of their firm's survival by leveraging their networking contacts to develop new relationships and gain access to extended networks. With the establishment of mutuality, trust, and independence among new ties, entrepreneurs are more likely to develop their social network and firms globally. (Figure 2).

In their early stages, most startups have only domestic relationships. As Englis, Wakkee, and van der Sijde (2007) found, these startups should leverage established ties (e.g., investors, customers, and suppliers), and work as brokers to build new ties. When their existing network is not suitable for working with new businesses or are found in narrow niches, startups could hire people who have network contacts that firm needs or who have foreign work experience. After they bridge

Table 1. Business internationalization stages and corresponding knowledge needs

Internationalization Stages

\begin{tabular}{|c|c|c|c|}
\hline & Foreign Market Intention & Active Involvement & Committed Involvement \\
\hline Key Activities & $\begin{array}{l}\text { - Exchange knowledge } \\
\text { - Recognize opportunity }\end{array}$ & $\begin{array}{l}\text { - Enter new market and find } \\
\text { new customers } \\
\text { - Locate, obtain, and control } \\
\text { resources }\end{array}$ & $\begin{array}{l}\text { - Develop new product and } \\
\text { market } \\
\text { - Gain competitive } \\
\text { advantage }\end{array}$ \\
\hline Knowledge Needs & $\begin{array}{l}\text { Technological and business } \\
\text { knowledge transformed into a } \\
\text { viable business opportunity by } \\
\text { matching attainable resources } \\
\text { and perceived market needs }\end{array}$ & $\begin{array}{l}\text { Experiential knowledge and } \\
\text { foreign institutional } \\
\text { knowledge for entering new } \\
\text { market and controlling diverse } \\
\text { resources }\end{array}$ & $\begin{array}{l}\text { - Highly privileged } \\
\text { information for non- } \\
\text { limitable benefits } \\
\text { - Specialized business } \\
\text { knowledge for generating } \\
\text { capital and strengthening a } \\
\text { dominant market position }\end{array}$ \\
\hline
\end{tabular}




\section{Obtaining Entrepreneurial Knowledge Needed for Internationalization}

\section{Chen Han and Adeleye Afolabi}

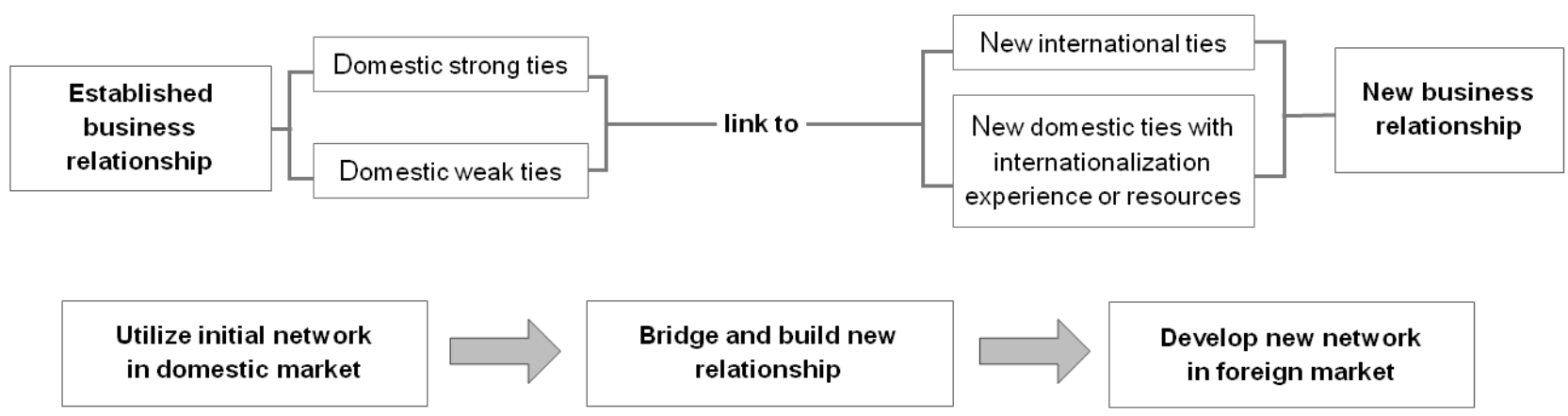

Figure 2. Social network and business relationship development

and build new relationships in international markets, ongoing business with customers and suppliers is also essential for new network development, for example, by offering products at a discount and asking international lead users to spread the word. As these new relationships grow, global startups accumulate knowledge and capabilities that empower them adapt to a new foreign market.

\section{Using existing networks for foreign market intention}

According to the review of the importance of various knowledge types through the three stages of internationalization, we now analyze how global startups manage and develop their social networks to meet their changing needs for knowledge based on the strength of different ties.

The initial idea to enter foreign markets may be found by scanning, selecting, and exploring existing relationships (Englis et al., 2007). Through interaction with strong ties (i.e., family, friends, other business actors with higher emotional intensity and reciprocal commitments) (Granovetter, 1973), the entrepreneur exchanges fine-grained information about target foreign market and rivals (i.e., business knowledge) and tacit technological knowledge, to lower risks in a new, uncertain environment. As a consequence, the opportunities that match their attainable resources and market needs can be identified and decisions can be made about whether or not they are worth pursuing (De Koning, 1999; Puhakka, 2002).

Furthermore, Granovetter (1973) and others have suggested that weak ties are also important in this process, because they provide access to novel information and thus to new options, especially when the entrepreneur needs diverse channels or approaches for seeking knowledge that go beyond their close relationships.
Thus, a balanced network of strong and weak ties is required to avoid being shielded or blind to multiple potential opportunities during preparation stages.

\section{Bridging and building new relationships}

To enter new foreign markets and control resource for international expansion, most entrepreneurs have to employ strategies that expand their current domestic networks, because the experiential knowledge and foreign institutional knowledge needed in this stage are generally distributed around the world. Using existing strong ties with "an indirect history and level of trust" (Sepulveda \& Gabrielsson, 2013) to develop and accumulate additional knowledge and capabilities, could save both time and money.

However, this approach may restrain the adaptive behaviour of firms if they only rely on strong ties for mutual learning or as a bridge to new contacts; it will expose them to risk in an unfamiliar environment, where they need timely detection and rapid response to mistakes caused by inexperience (Sharma \& Blomstermo 2003). Hence, firms also need to use weak ties (e.g., a diverse set of persons working in different contexts) to gain access to unconnected network actors for seeking complementary knowledge about target foreign market that "go outside their existing channels" (Sharma \& Blomstermo, 2003). Thus, weak ties are better than strong ties in providing a beachhead or entry node to support rapid international expansion.

\section{Developing new networks for committed involvement}

In the stage of committed involvement, global startups pay attention to legitimacy and gaining competitive advantage. Specialized knowledge and highly privileged information are required to establish a strong market position. 


\section{Obtaining Entrepreneurial Knowledge Needed for Internationalization}

Chen Han and Adeleye Afolabi

After building new business relationships in foreign markets, entrepreneurs need to continue to develop their network, making it more attractive to new and more influential network partners (Hite \& Hesterly, 2001), in order to enhance their ability to gaining differentiated knowledge and building positive resource flows. Over time, these changes increase the density and interdependence of the new international network (Sepulveda \& Gabrielsson, 2013). So, firms should try to transform new ties into well-known relationships with trust, then through them, develop more weak ties, which gives the firm a higher centrality in their network for receiving more, better, and early knowledge compared to their competitors (Sharma \& Blomstermo 2003).

\section{Conclusion}

Knowledge-based resource and capabilities determine the direction of the opportunities and how to transform the initial idea into the offering (Englis et al., 2007) for legitimacy and improved chances of survival in international markets. The main focus of this article is how to meet an entrepreneur's knowledge-based need for internationalization. The intention is to provide entrepreneurs a roadmap and vision for understanding some of the necessities and development patterns for internationalization, as well as a guide of strategies adopted for utilizing and developing social capital.

This article has reviewed literature on knowledge-based resources, the internationalization process, and the value of networks for new ventures. It brought together insights to analyze three key problems faced by international entrepreneurs in terms of what types of knowledge are needed at various stages of internationalization and how to acquire them. The contributions of this article include the categories of needs for knowledge (Figure 1), a synthesis of the changing needs for knowledge at each stage (Table 1), and a list of strategies combined with social network development and tie strength (Figure 2).

For researchers and scholars studying networks and internationalization, more research is needed to examine the role of social network in the internationalization process for ventures from different industries and in different position in networks, because the value of a social network depends on the position of actors in social hierarchies, the number of competitors (Burt, 1997), the entrepreneurs' connections with brokers, and the specific instrumental actions performed. Other research could be conducted to link the entrepreneurs' ability of absorbing and internalizing knowledge to the performance of international ventures, if possible, from multiple countries with various cultural backgrounds.

In summary, entrepreneurs must be aware that each of the three phases of the internationalization process have different knowledge needs, so network and business relationships must be developed to fulfill these needs. Moreover, for internationalization, it is important to rely on local networks to build and bridge relationships, through which entrepreneurs can develop new networks in new markets. In addition, when using social capital, all ties should be seen beneficial to entrepreneurs, but the entrepreneur's situation determines which ties are more beneficial than others.

\section{About the Authors}

Chen Han is a graduate student in the Technology Innovation Management (TIM) program at Carleton University in Ottawa, Canada. She has more than eight years working experience in product design, user experience design, and project management. She built and led an independent technical team to provide overall solutions and outsourcing services for various clients including world's top media, Internet startups, and multinational firms. Currently, she is working with the founder team of Pricebeater, a international startup offering tools for online shopping in North America.

Adeleye Afolabi is a graduate student in the Technology Innovation Management (TIM) program at Carleton University in Ottawa, Canada. He also holds a Bachelor's degree in Information Resources Management from Babcock University in Nigeria. He is a business-driven technology enthusiast with highlevel management experience as the co-founder of Aregen Apparel, Afolexy Project Limited, and Abidafosi Enterprises; a smart-casual clothing company, a registered trucking and haulage business, and a petroleum transport company, respectively. He has work experience in the fields of broadcasting (streaming and telnetting) and finance, with Zenith Bank Group. His research interests include technopreneurial innovation, business information management, and social media marketing. 


\title{
Obtaining Entrepreneurial Knowledge Needed for Internationalization
}

\author{
Chen Han and Adeleye Afolabi
}

\section{References}

Brush, C. G,. Greene, P. G., Hart, M. M., \& Haller, H. S. 2001. From Initial Idea to Unique Advantage: The Entrepreneurial Challenge of Constructing a Resource Base. Academy of Management Executive, 15(1): 64-80.

http://www.jstor.org/stable/4165711

Burt, R. S. 1997. The Contingent Value of Social Capital. Administrative Science Quarterly, 42(2): 339-365.

http://dx.doi.org/10.2307/2393923

Coviello, N. E., \& Cox, M. P. 2006. The Resource Dynamics of International New Venture Networks. Journal of International Entrepreneurship, 4(2-3): 113-132.

http://dx.doi.org/10.1007/s10843-007-0004-4

Coviello, N. E., \& Munro, H. 1997. Network Relationships and the Internationalisation Process of Small Software Firms. International Business Review, 6(4): 361-386. http://dx.doi.org/10.1016/S0969-5931(97)00010-3

De Clercq, D., \& Arenius, P. 2006. The Role of Knowledge in Business Start-up Activity. International Small Business Journal, 24(4): 339358.

http://dx.doi.org/10.1177/0266242606065507

De Koning, A., \& Muzyka, D. 1999. Conceptualizing Opportunity Recognition as a Socio-Cognitive Process. SSE/EFI Working Paper Series in Business Administration, No 1999:13. Stockholm, Sweden: The Centre for Advanced Studies in Leadership.

Dyer, J. 1996. Specialized Supplier Networks as a Source of Competitive Advantage: Evidence from the Auto Industry. Strategic Management Journal, 17(4): 271-291. doi:10.1002/(SICI) 1097-0266(199604)17:4<271::AIDSMJ807>3.0.CO;2-Y

Englis, P. D., Wakkee, I., \& van der Sijde, P. 2007. Knowledge and Networks in the Global Startup Process. International Journal of Knowledge Management Studies, 1(3/4): 497-514. http://dx.doi.org/10.1504/IJKMS.2007.012538

Eriksson, K., Johanson, J., Majkgård, A., \& Sharma, D. D. 1997. Experiential Knowledge and Cost in the Internationalization Process. Journal of International Business Studies, 28: 337-360. http://dx.doi.org/10.1057/palgrave.jibs.8490104

Fleisher, C. S., \& Bensoussan, B. E. 2007. Business and Competitive Analysis: Effective Application of New and Classic Methods. FT Press.

Gabrielsson, M., Kirpalani, V. H. M., Dimitratos, P., Solberg, C. A., \& Zucchella, A. 2008. Born Globals: Propositions to Help Advance the Theory. International Business Review, 17(4), 385-401. http://dx.doi.org/10.1016/j.ibusrev.2008.02.015

Greve, A., \& Salaff, J. W. 2003. Social Networks and Entrepreneurship. Entrepreneurship Theory and Practice, 28(1), 1-22. http://dx.doi.org/10.1111/1540-8520.00029
Hakansson,H., \& Snehota, I. (Eds.) 1995. Developing Relationships in Business Networks. London: Routledge.

Hite, J. M., \& Hesterly, W. S. 2001. The Evolution of Firm Networks: From Emergence to Early Growth of the Firm. Strategic Management Journal, 22(3): 275-286. http://dx.doi.org/10.1002/smj.156

Hohenthal, J., Johanson, J., \& Johanson, M. 2014. Network Knowledge and Business-Relationship Value in the Foreign Market. International Business Review, 23(1): 4-19. http://dx.doi.org/10.1016/j.ibusrev.2013.08.002

Javernick-Will, A., \& Levitt, R. E. 2009. Mobilizing Institutional Knowledge for International Projects. Journal of Construction Engineering and Management, 136(4): 430-441. http://dx.doi.org/10.1061/(ASCE)CO.1943-7862.0000110

Kuemmerle, W. 2002. Home Base and Knowledge Management in International Ventures. Journal of Business Venturing, 17(2): 99-122. http://dx.doi.org/10.1016/S0883-9026(00)00054-9

Oviatt, B. M., \& McDougall, P. P. 1994. Toward a Theory of International New Ventures. Journal of International Business Studies, 25(1): 45-64. http://dx.doi.org/10.1057/palgrave.jibs.8490193

Penrose, E. T. 1959. The Theory of the Growth of the Firm. Oxford: Basil Blackwell.

Puhakka, V. 2002. Entrepreneurial Business Opportunity Recognition: Relationship between Intellectual and Social Capital, Environmental Dynamism, Opportunity Recognition Behavior, and Performance. D.Sc. Thesis. Universitas Wasaensis.

Schumpeter, J.A. 1934. The Theory of Economic Development. Cambridge: Harvard University Press.

Sepulveda, F., \& Gabrielsson, M. 2013. Network Development and Firm Growth: A Resource-Based Study of B2B Born Globals. Industrial Marketing Management, 42(5): 792-804. http://dx.doi.org/10.1016/j.indmarman.2013.01.001

Shane, S. 2000. Prior Knowledge and the Discovery of Entrepreneurial Opportunities. Organization Science, 11(4): 448-469. http://dx.doi.org/10.1287/orsc.11.4.448.14602

Sharma, D. D., \& Blomstermo, A. 2003. The Internationalization Process of Born Globals: A Network View. International Business Review, 12(6): 739-753. http://dx.doi.org/10.1016/j.ibusrev.2003.05.002

Slotte-Kock, S., \& Coviello, N. 2010. Entrepreneurship Research on Network Processes: A Review and Ways Forward. Entrepreneurship Theory and Practice, 34(1): 31-57. http://dx.doi.org/10.1111/j.1540-6520.2009.00311.x

van der Veen, M., \& Wakkee, I. A. M. 2004. Understanding the Entrepreneurial Process. In D. S. Watkins (Ed.) Annual Review of Progress in Entrepreneurship Research, 2002-2003, 2: 114-152. Brussels: European Foundation for Management Development. 